\title{
High Order Thinking Skills: Strategies for Raising Student's Thinking Processes and Children's Cognitive Development in Reading Comprehension
}

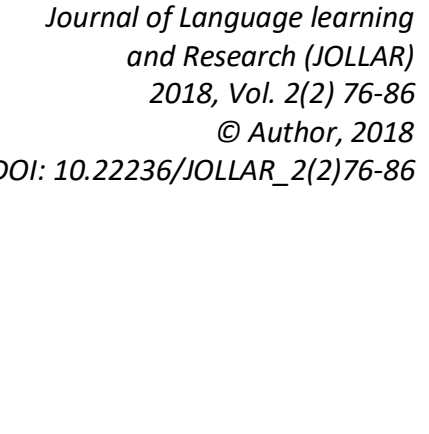

\section{Reni Anggraeni ${ }^{1}$}

Universitas Muhammdiyah Prof. DR. HAMKA, Indonesia

Artikel ini memaparkan beragam strategi untuk meningkatkan kemampuan berpikir tingkat tinggi (HOTS) siswa dalam membaca. Pada dasarnya, untuk dapat mencapai kemampuan HOTS ini, siswa didorong untuk melakukan proses berpikir yang lebih baik, sehingga strategi yang digunakan HOTS akan mencapai hasil yang memuaskan. Seperti halnya perkembangan kognitif, HOTS lebih tepat dilakukan sejak anak-anak. Strategi untuk meningkatkan kemampuan berpikir kritis dalam membaca dapat digambarkan melalui tiga cara berikut: 1) tujuh strategi yang diusulkan oleh Dewan Membaca Nasional, Keterampilan membaca kata yang diusulkan oleh Mellard dkk (2010), dan 3) pengetahuan kosakata yang diusulkan oleh Wise dkk (2007). Artikel ini dikembangkan berdasarkan pentingnya pentingnya keterampilan abad 21 yang diusulkan oleh National Commission on Excellence in Education, Common Core State Standards Initiative, Partnership for 21 Century Skills, and Secretary's Commission on Achieving Necessary Skills untuk dimasukan pada kurikulum pendidikan saat ini. Manurut organisasi tersebut, siswa dan generasi muda abad 21 dituntut untuk mendapatkan soft skills spesifik yang terkait langsung dengan bagaimana mereka mendapatkan kemampuan berpikir tingkat tinggi.

Kata kunci: kemampuan berpikir tingkat tinggi (HOTS), berpikir kritis, proses berpikir, soft skills.

${ }^{1}$ Corresponding author: reni.anggraeni1003@gmail.com 
This article presents various strategies for raising student's high order thinking skills (HOTS) in reading comprehension. Basically, to be able to raise the capability of HOTS, a student is encouraged to have better thinking processes so that varied strategies to implement HOTS will work out properly and accordingly. Just like children' cognitive development, HOTS is best put into practice since early childhood. The strategies to improve the student's critical thinking skills in reading comprehension are described thoroughly in three different ways: 1) seven strategies proposed by the National Reading Panel, 2) word reading skills proposed by Mellard et al. (2010), and 3) Vocabulary knowledge proposed by Wise et al. (2007). This article is developed based on the importance of $21^{\text {st }}$ century skills proposed by National Commission on Excellence in Education, Common Core State Standards Initiative, Partnership for 21 Century Skills, and Secretary's Commission on Achieving Necessary Skills to be included in today's curriculum. According to the one of the organisations proposing the $21^{\text {st }}$ century skills, students and young generation are demanded to be able to acquire specific soft skills pertaining to critical thinking.

Keywords: high order thinking skills (HOTS), critical thinking, thinking process, soft skills

\section{PENDAHULUAN}

The concept of High Order Thinking Skills (HOTS) has been explicitly stated in the $21^{\text {st }}$ skills in which its content can be different from one study to another. The way a researcher, author, or organization defines HOTS is also different (Ilyas, 2017, 2019). Also, the difference exists in the specific elements of critical thinking. For example, the US Secretary of Education mandated the National Commission on Excellence in Education (1983) to identify a list of skills which is extremely needed in today's fast rapid development of education in the US. From the investigation, a list of skills and abilities obtained became the pillar and basic foundations of some disciplines implemented in various universities, i.e. 1) passion for learning, 2) comprehension or mastery, 3) learning implementation, 4) critical thinking and cognitive, 5) communication which is integrated to be able to construct good sentences and grasp the message delivered in audio visual vis-à-vis listening tapes, to review topics critically, and be fluent in a foreign language, 5) social sciences, understanding and implications, 6) technology, able to operate computer and its utilities and facilities, 7) learning experience in all types of discipline, such as humanistic and arts.

Compared to the investigation conducted by the National Commission on Excellence in Education pertaining to HOTS, the Common Core Standards (2010) concluded that the skills required for students to be compatible with their career path were that they should possess 1) the ability of debating or giving inputs, opinions, or even feedback through strong reasoning, 2) the ability of collecting 
authentic and original evidence, 3) critical thinking, problem-solving and analytical capabilities, and 4) interaction. In contrast, HOTS which is unquestionably needed to young learners or people to possess had been thoughtfully investigated by the Secretary's Commission on Achieving Necessary Skills (SCANS, 1991) established by the U.S. Secretary of Labour.

Based on the report entitled "What Work Requires of Schools", the term 'HOTS' was stated in different terms, i.e. learning a living, which was still in reference to the goal of sustaining young people' competencies to be integrated with the types of skill included in HOTS, namely 1) primary skills consisting of crucial skills, such as reading, writing, listening and speaking, intellectual skills, such as acquiring a creative thinking ability, being able to decide comprehensively, solving challenging obstacles, possessing a visualized-oriented paradigm, knowing how to be an independent learner, and reasoning, and individual qualities, such as performing responsibility, possessing self-confidence, being able to interact with others in society, having a good self-discipline skill, and showing honor and trustworthiness, and 2) workplace competencies consisting of sources, such as classifying, systematizing, formulating, and involving varied resources, selfreflection, such as being able to work in team, data, such as obtaining materials to analyze, evaluate, and communicate further, scheme, such as being able to comprehend congruent varied relations, and technology, such as being able to operate kinds of computational devices as part of the technology.

The awareness of how important the implementation of HOTS to be part of young people's future had also been well-defined and formulated by a NonGovernment Organization (NGO), Partnership for $21^{\text {st }}$ Century Learning (P21, 2002). A research was conducted by P21 aiming to identify the skills appropriate for being adapted in the $21^{\text {st }}$ Century demands, so that it would be applicable to the US K-12 education which was divided into two classification, namely the 7C skills containing 1) critical thinking and problem solving, 2) creativity and innovation, 3) cross-cultural understanding, 4) communications, information, and media literacy, 5) computing and ICT literacy, 6) career, and learning self-reliance, and the 4C skills consisting of 1) collaboration, 2) communication, 3) critical thinking, and 4) creativity.

Mctighe \& Schollenberger (1991) has also long proposed that the essence of learning, instead of using the term HOTS, is basically to acknowledge that the area of skills needed to be compatible with the demands of 21 st century competencies is not only by mastering reading, writing and arithmetic, but also by showing good skills in interaction, solving high level of difficulties, and being knowledgeable both in scientific and high-tech computational devices. Thus, he stated that the three mentioned items are currently the tools to make one adjustable adequately to the evolving era of technological rapid advancement. Further, he 
claimed that if one is able to be a problem solver as well as to show such outstanding critical thinking abilities applied in most all disciplines, this refers to the goal of what HOTS is really for which means that the objectives are achieved successfully.

Teaching English as a Foreign Language (EFL) or Teaching English as a Second Language (ESL) will not be sufficient if just depending on the conventional teaching methods. Many studies have been conducted as to learning difficulties or students' understanding in having good comprehension in English subjects. Somehow, it does not make sense to achieve the students' learning objectives which are to master the four language skills, such reading, listening, speaking and writing, when they themselves cannot even grasp the content of the learning materials given by the teacher because the classic or the so-called conventional methods are still reigned the teaching and learning processes. Thus, it is necessary for teachers to be acknowledged with the presence of high order thinking skills (HOTS). They are expected to be well-adjusted with the integration of HOTS into their teaching strategies and be able to achieve the end product of student's learning improvement as the result of adopting HOTS in all subjects pertaining to the four mentioned language skills.

The concept of high order thinking skills may have been widely spread to language teachers as well as education personnel. However, very few who have deep understanding and comprehension on how to really put the adoption of HOTS into practice and implement it in the classroom, or make it possible to be a customary way of teaching as well as learning between teachers and students. Therefore, this article provides strategies of how to encourage students' HOTS in reading comprehension.

\section{RAISING STUDENT'S HIGH ORDER THINKING SKILLS IN READING COMPREHENSION}

\section{The Seven Strategies Proposed by the National Reading Panel}

As stated by Mckown \& Barnett (2007), the student's learning objectives, which one of them is to have deep comprehension on reading skills, are so possible to be true and real as long as the teachers know how to raise their critical thinking abilities. Based on a research conducted by the Ministry of Education and Culture of the Republic of Indonesia, all children have the competency of HOTS attached in their mind, but it depends whether or not the teachers are able to raise and trigger the HOTS to come into the surface. Unfortunately, how many teachers out there who are loyal to adopt the classic or the conventional methods even if the end product of the student's learning objectives may not be as satisfied as it has been expected before? The National Reading Panel (NRP, 2000) identified seven strategies which can be implemented by teachers. The seven strategies are as follows: 


\section{Phonemic Awareness}

Teaching phonemic awareness to young learners is said to be one of the ways of raising high order thinking skills when their cognitive development is still wellformed and in progress because they are not only able to grasp and imitate the sounds produced by other people surround but also able to classify the sound coming from oral conversation between adults as it has been the key factor to master the reading skills. The National Reading Panel (2000) also claimed that students who learned English as a Second Language (ESL) had resulted some fruitful learning improvement.

\section{Phonics}

The ability to be able to operate the high order thinking skills may not be easily acquired by students. Some may have hard time to deal with it; some may not. It really depends on the way their mind work with difficult things, mainly on how they are able to manage and process the stimulus given by external forces. If a group of students are able to cope with the stimulus given by outsiders and operate them accordingly, it might be because they have been accustomed to sharpening their critical thinking since childhood. As what has been stated by Addler (2001), children are so easy to be taught using the strategies of raising their high order thinking skills, i.e. the phonics instructions, due to their young age. The way they learned was not the same as adult learners learned.

Through phonetics instructions, children start to be familiar with the sounds or words uttered by the surroundings, e.g. parents, teachers, friends, etc. Their cognitive development is able to relate the connections between words they have learned in a very simple form of writing, i.e. the consonants and vowels, and the sounds they heard through adults' conversation or when the adults or friends as their age talked to them. Addler (2001) also states that the authenticity of the strategy can be proved by the L2 young learners of English language who were taught by the same strategy. Having been taught through the phonetics instruction, children' ability of recognising words, spelling and reading comprehension improved.

\section{Fluency}

According to the National Reading Panel (2000), Students' high order thinking skills that come into the surface is not such a hard task if the teacher is creative enough to implement an efficient strategy during the teaching and learning practices. As claimed by the NRP, the reading exposure with the use of fluency technique proves to be useful in raising HOTS. The technique was by reading a textbook or stories as fluent, precise and fast as students can. In addition, NRP (2000) states that the benefit of adapting the fluency technique into reading also shapes students' imaginary mind pertaining to the story that they have just read. 
However, this strategy may be adaptable and best-implemented in L1 speakers of English language, because this strategy may not be that easy to execute and cannot be compared to the ability of $\mathrm{L} 1$ speakers. The range of reading difficulties for L2 speakers may not also be the same as the way the L1 speakers has because the L1 speakers must have understood the meaning of every word written in the textbook or stories as they may have been accustomed to hearing and speaking the language in daily lives while communicating with parents at home or friends at school. Instead, for L2 speakers of English language, they must work so hard to be able to read and understand the meaning contained in every word of the story. This will not be an easy task to be equal in terms of mastering and understanding reading comprehension between L1 and L2 speakers of English language. Even if, the end product is to sharpen students' imaginary mind when they read a sort of given stories through reading with fluency technique. Still, this can never be easy for L2 to produce such imagination. Fluency may not be the first step to take into account for the type of strategy regarding with raising the high order thinking skills of the students implemented in classroom activities because they need to be familiar first with the words written in the stories through some kind of listening activities as an approach.

\section{Vocabulary}

Teaching vocabularies can be another strategy to foster the high order thinking skills. The National Reading Panel (2000) proposes that this strategy could bring to light the students' critical thinking when the teacher teach them words that are familiar between their ears and the intensity of the words usage is quite regular. The strategy of teaching vocabularies to students can be by self-learning which means that they read the books or stories by themselves. Another way is by building communication to people around them so that it can become a habitual conversation, or the adults, i.e. parents, older sisters or brothers, or friends, who can read them a book of short stories compilation because this was the way children grasp and enrich the bank of their vocabularies capacities.

NRP (2000) also mentions that students from lower class society are identified to be having some difficulties to collect more vocabularies and understand them because they have less opportunities to receive vocabularies spoken by L1 speaker of English language through direct conversation. This statement may not always be true or valid just because the opportunity to speak or have a conversation directly with the L1 is limited or even no chance at all. To awake the high order thinking skills, students who live in non-English speaking countries can also do that. As stated by the NRP (2000), extensive reading can also facilitate students to construct their own critical thinking. The statement made by the NRP can be the ground that basically those students, who are born and have 
been living in non-English speaking countries, are also possible to alert themselves toward the importance of building the high order thinking skills which is, in this regards, by doing the extensive reading, whereas it is also a part of the components of language exposure. In short, critical thinking can be constructed little by little just by reading English-written books extensively even if there are no L1 speakers of English language to speak to or have conversation with.

\section{Comprehension Strategies}

The National Reading Panel (2000) claim that the reading comprehension could be one of the strategies to raise student's critical thinking skills because it is more to how capable one's thinking process automatically produce meanings when reading a written text or source. Specifically, students will be able to understand a written text when their mind is occupied with the 'thinking process' which functions to create meanings. As they have been well-adjusted with the analytical devise, the thinking process means that the strategy of reading comprehension starts to develop and take part in their mind. Unfortunately, today's teachers tend to teach types of subjects which are not pertaining to activities that can sharpen student's critical thinking skills through the strategy of reading comprehension, so that their thinking process will be accustomed to working out difficult tasks by producing its meanings when they are reading.

As a matter of fact, the statement made by the NRP (2000) about that particular thing related to the way teacher teaches and chooses the learning subjects is just too sad to be true, especially when it is what the reality is. As reported by Widiyani (2018), Indonesian teachers' interest in literacy is still low, and they are lack of motivation to encourage themselves to conduct self-study by reading books with regard to their area of interest and professionalism.

\section{Teacher Education}

Another study conducted by the National Reading Panel (2000) declares that teacher education matters to raise the student's high order thinking skills. Furthermore, the NRP mentions that teacher education has been considered as one of the innovative and proper strategies because it takes specific requirements to bring to light student's critical thinking skills and encourage the skills through reading comprehension. If the teachers have no required competencies and abilities to do the job correctly, it would be assured that the range of difficulty to construct the student's critical thinking skills might be hard and full of challenges. A wellmanaged teachers in terms of preparing themselves with sufficient knowledge and competencies will make instructions which could encourage students' critical thinking skills. 


\section{Metacognition}

The National Reading Panel (2000) reports that the strategy of metacognition is essential to build the student's high order thinking skills. It is quite easy to differentiate between students who possess the metacognitive sense and students who do not have this particular sense of self-awareness toward learning development. Students who can alert themselves whether or not the way they do can achieve learning objectives are those who have the metacognitive system in their thinking process. These types of students who know exactly how far their comprehension, starting from the beginning until the end of reading a written text, are the ones labelled as 'good readers' because of their metacognitive skills. On the contrary, there are also students who have no metacognitive system. They lack intuition and eagerness to understand of what the text was really about. Consequently, they are easy to give up instead of having deep curiosity about the written text was about. They make little effort in order to be able to understand the text that they are reading.

NRP (2000) concludes that it is only for students categorized as 'good readers' who seem to have the invitation from the teachers to participate in a special program related to metacognition. This claim, however, should not only target special classes to improve students' metacognition but also target students who are still in need of assistance to make better their low metacognitive competency in reading. Basically, all types of students were gifted to be having their own metacognitive device attached in their mind, but the thing is that some may know precisely how to make it appear while the others may just wait for someone to do that for them, which is to teach and guide them how to best raise their metacognition, because they just do not even know how to do that. In this regard, it is the teacher who is the one that can provide these such important needs and help the students with metacognitive skills and competencies.

\section{Word Reading Skills Proposed by Daryl F. Mellard, Emily Fall, and Kari L. Woods}

Mellard et al. (2010) mention that adult learners with poor literacy competence still have the capability to improve their reading comprehension toward a given written text by the help of word reading strategy. The range of age of the adult learners who participated in the research was varied from 16 to 64 years, but yet their age difference between the younger learners and the older learners had no congruency with the success of implementing the word reading skills as the strategy of raising the adult learners' high order thinking skills through reading comprehension. Moreover, even if they were categorized as adult learners, the way they obtained the reading comprehension was by connecting one sentence to another in which this type of learning improvement was as equal as young readers 
Unlike young readers, adult learners still found hard time to construct two different strategies, i.e. the word reading skills and vocabulary knowledge, to be practiced at the same time when they were given a written text for enhancing their reading comprehension. Mellard et al. (2010) state:

Instead, they function somewhat like young readers, relying on word reading skills to understand connected texts-yet their phonemic decoding ability averages 3.8-grade equivalent and word reading averages 5.0-grade equivalent. Moreover, they have not developed or acquired the ability and strategies required to integrate their word reading skills with vocabulary knowledge and other language comprehension skills for the purpose of reading comprehension (p. 163)

In short, this strategy is a breakthrough to add in the bank of knowledge pertaining to the way to raise HOTS. However, the range of participant's age from the younger until the oldest ones was quite great. The result of the research would be more fruitful to just limit the participant's age from 16 to 40 years, instead of from 16 to 64 years.

\section{Vocabulary Knowledge Proposed by Justin C. Wise, Rose A. Sevcik, Robin D. Morris, Maureen W. Lovett, and Maryanne Wolf.}

The study by Wise et al. (2007, p. 1107) regarding the best strategy of increasing student's critical thinking skills in reading comprehension resulted such an interesting finding. The area of strategy of vocabulary knowledge was divided into two categories. One was the receptive vocabulary knowledge, and the other one was expressive vocabulary knowledge. These two 'red-line' types of the division of vocabulary knowledge were not attached, or in other words, no relation at all with the reading comprehension, mainly the pre-reading skills. However, only the category of expressive vocabulary knowledge could be assumed to have a relation with how a child was able to distinguish words because, indeed, the child must have skills to identify various words.

This statement proves that teaching the strategy of raising HOTS in reading comprehension since early childhood has been successful to acknowledge that children' cognitive development is still afresh to start implementing the strategy as soon and early as possible. The strategy of increasing HOTS in early age, specifically to achieve better reading comprehension, is strongly advised because children are easy to adapt and receive stimulus from external factors, i.e. their teachers and parents. Wise et al. (2007) state that "this study provided unique evidence that receptive and expressive vocabulary knowledge were independently 
related to pre-reading skills, whereas only expressive vocabulary knowledge was related to word identification abilities" (p. 1107).

\section{CONCLUSION}

Various strategies of raising the importance of high order thinking skills in students' thinking process and children' cognitive development, more importantly, in reading comprehension, are crucial. Once a teacher is able to prove that critical thinking skills can be brought to light through its variety strategies and become the spotlight of the area concerned, these will be the strong and future-oriented pillars toward the student's understanding as well as comprehension of raising their own high order thinking skills in reading written texts. In fact, these will also be the way to sharpen their critical thinking skills, especially if the teachers are capable of using more innovative, varied, and effective strategies to encourage students' high order thinking skills.

\section{REFERENCES}

Common Core State Standards Initiative. (2010). Frequently Asked Questions. Retrieved January $\quad 12$, 2018, from http://www.corestandards.org/assets/CoreFAQ.pdf

Ilyas, H. P. (2017). Historical perspective: The development of critical thinking in Indonesian ELT. Journal of ELT Research, 2(2), 89-102.

Ilyas, H. P. (2019). The quest for critical thinking framework in ELT. CELT Journal, 18(2), 304-326.

McTighe, J., \& Schollenberger, J. (1991). Why teach thinking? A statement of rationale. In A. L. Costa (Eds.), A resource book for teaching thinking (pp.1415). Virginia: Association for Supervision and Curriculum Development.

Mckown, B.A. \& Barnett, C.L. (2007). Improving reading comprehension through higher-order thinking skills (Unpublished Master thesis), Saint Xavier University, Chicago, Illinois, the United States of America.

National Commission on Excellence in Education. (1983). The imperative for educational reform. Washington, D.C., the United States of America.

National Reading Panel. (2000). Teaching children to read: An evidence-based assessment of the scientific research literature on reading and its implications for reading instruction. Retrieved January 5, 2018, from https://www1.nichd.nih.gov/publications/pubs/nrp/ Documents/report.pdf

Partnership for 21 Century Skills. (2008). 21 $1^{\text {st }}$ Century skills, education and competitiveness: A resource and policy guide. Arizona, the United States of America: Author.

Secretary's Commission on Achieving Necessary Skills, (1991). What work requires of schools: A scans report for America 2000. Washington, D.C., the United States of America: Author.

Widiyani, R. (2016, April 19). Minat guru terhadap literasi masih rendah [Teacher's interest in literacy remains low). Harian Nasional. Retrieved January 18, 
2018, from http://www.harnas.co/2016/04/19/minat-guru-terhadap-literasimasih-rendah.

Mellard, D.F., Fall, E., \& Woods, K.L. (2010). A path analysis of reading comprehension for adults with low literacy. Journal of Learning Disabilities, 43(2), 154-165.

Wise, J. C., Sevcik, R. A., Morris, R. D., Lovett, M.W., \& Wolf, M. (2007). The relationship among receptive and expressive vocabulary, listening comprehension, pre-reading skills, word identification skills, and reading comprehension by children with reading disabilities. Journal of Speech, Hearing, and Hearing Research, 50(4), 1093-1109. 